Psychological Topics, 27 (2018), 1, 33-53

Original Scientific Paper - UDC - 591.434

616.379-008.64

\title{
Gut Microbiota and Body Weight - A Review
}

\author{
Ioana Duca, Flaviu Rusu, Alexandra Chira, and Dan Lucian Dumitrascu \\ Iuliu Hatieganu University of Medicine and Pharmacy, \\ $2^{\text {nd }}$ Medical Department, Cluj-Napoca, Romania
}

\begin{abstract}
The link between gut microbiota and insulin resistance has an important clinical impact, people affected by dysbiosis having a predisposition for developing: obesity, type 2 diabetes mellitus, nonalcoholic fatty liver disease, cancers, cardiovascular, neurodegenerative and psychiatric diseases. Dysbiosis may lead through chronic inflammation to obesity and metabolic syndrome. We carried out a systematic review of the studies dedicated to the role of gut microbiota in weight gain and obesity. A systematic literature search of recent data published in electronic databases, was performed, using as search phrase: "gut microbiome and body weight and obesity". Studies that contained no data about the influence of gut microbiota changes on obesity were excluded. Western diet, antibiotic use in childhood, excessive maternal pre-pregnancy weight, Cesarean delivery, and testosterone deficiency are triggers of the alteration of microbiota and subsequently the appearance of obesity. Predominance of Firmicutes and anaerobic genera, changes in the mycobiome and viral intestinal population are implied in the etiology of obesity. Prebiotics, polyphenols, different herbs, medication (antidiabetics, calcium), physical exercise, rich fibre intake and bariatric surgery are the most important therapeutic options. Personalized dietary treatments, antiviral agents and mycobiome manipulation would represent the new target in treating obesity. Any change of the quantitative and qualitative composition of microbiota has influence on the components of metabolic syndrome, so any management strategy for the treatment or prevention of obesity in children and adulthood should have the microbiome as target.
\end{abstract}

Keywords: diabetes, metabolism, microbiota, obesity

\section{Introduction}

Gut microbiota actually represents an active biomass, from a metabolic point of view, any change in the composition and/or abundances of different bacterial species may predict the progression toward metabolic syndrome. It has an important role in maintaining homeostasis; although the direct relationship between microbiota and various disorders is still unclear, predominance of some phyla and quantitative and

Dan Lucian Dumitrascu, 2 ${ }^{\text {nd }}$ Medical Clinic, Clinicilor Street 2-4, 400006 Cluj-Napoca, Romania. E-mail: ddumitrascu@umfcluj.ro 
both qualitative imbalance of different species has an important impact on creating a chronic inflammatory state, which leads to obesity and diabetes. The human gastrointestinal microbiota consists of $10^{14}$ microorganisms $/ \mathrm{ml}$ of luminal content, belonging to over 5000 bacterial species, $90 \%$ of them belong to the Bacteroidetes phyla. The link between gut microbiota and insulin resistance has an important clinical impact, people affected by dysbiosis have a predisposition for developing: obesity, type 2 diabetes mellitus (T2DM), non-alcoholic fatty liver disease (NAFLD), cardiovascular, neurodegenerative and psychiatric diseases (mental illness, dementia, depression), cancers (gastric, colorectal, esophageal, liver and pancreatic carcinomas) (Bruce-Keller et al., 2015; Koh et al., 2016; Saad, Santos, \& Prada, 2016). The aim of this paper is to review the mechanisms of implication of microbiota in obesity, as well as the possible therapeutic strategies beneficial to lose weight, and to prevent/treat the components of metabolic syndrome by acting on the microbiome. The importance of microbiota implication in obesity has been described in different reviews up to now, among them the most important are: Saad et al. (2016), Oh, Ahn, and Cho (2016), Nehra, Allen, Mailing, Kashyap, and Woods (2016), and Ghazalpour, Cespedes, Bennett, and Allayee (2016).

\section{Methods}

A systematic literature search of recent data published in electronic databases, including PubMed and ISI Web of Science, was performed for all studies assessing the influence of gut microbiota changes on obesity (from $1^{\text {st }}$ January 2015 to $1^{\text {st }}$ October 2017). The search strategy included text terms and Medical Subject Headings (MeSH) for microbiota and obesity: "gut microbiome and body weight and obesity". The "related articles" function in PubMed was also used to identify articles not found in the original search.

\section{Inclusion Criteria}

The inclusion criteria used were: abstracts and full-text journal publication, including data about pathogenetic mechanisms of gut microbiota in inducing obesity, and treatment options in the metabolic syndrome. Papers in English, French, German and Polish were included in the study, or in any other language, but with an English abstract. The titles and abstracts of all identified studies were reviewed and then confronted by independent authors (between $1^{\text {st }}$ January 2015 to $31^{\text {st }}$ December 2016 by: ID and FR, and between $1^{\text {st }}$ January 2016 to $1^{\text {st }}$ October 2017 by: AC and DLD) according to the Meta-analyses Of Observational Studies in Epidemiology (MOOSE) criteria. 


\section{Exclusion Criteria}

Studies were excluded if they were editorials or letters to the editor, or did not meet the inclusion criteria; these were papers containing general literature data about gut microbiota and obesity, but without mentioning any study or any precise therapeutic option for weight gain.

\section{Results}

The first search resulted in a total of 201 articles. After reviewing the abstracts, we kept 184 studies, which described the mechanisms of the gut microbiota implication in obesity and therapeutic options and thus met our inclusion criteria. Included articles were published between $1^{\text {st }}$ January 2015 and $1^{\text {st }}$ October 2017. The 17 excluded articles mentioned the implication of gut microbiota in obesity in general, or did not mention anything about the treatment, or did not have an available abstract.

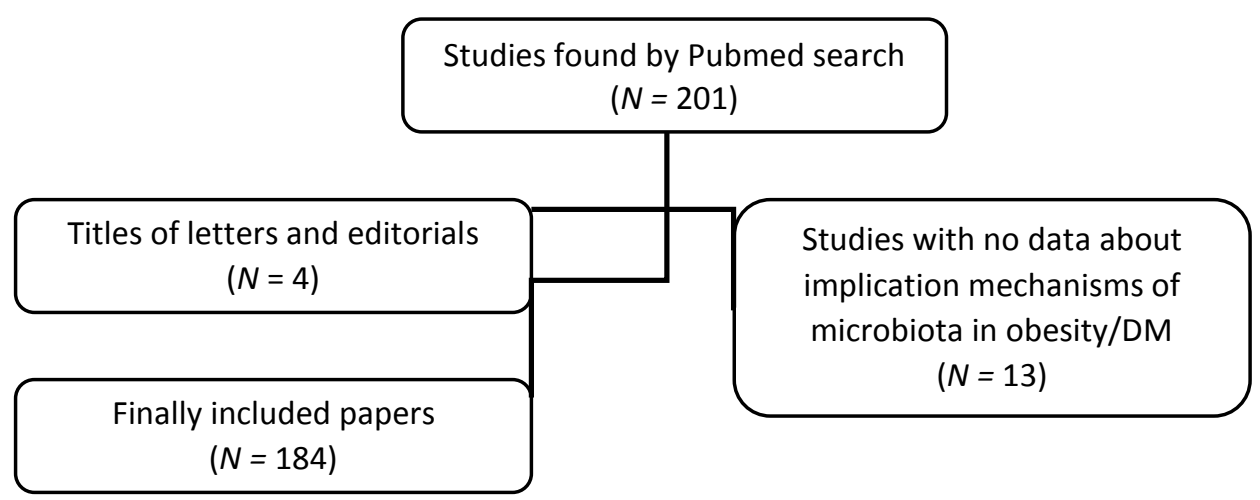

Figure 1. The Selection of Papers for this Analysis.

\section{Implication of Microbiota in Human Obesity}

\section{Etiopathogenesis}

Davis, Yadav, Barrow, and Robertson (2017) showed that Westernized diet proved to be a more severe factor in causing dysbiosis as compared to an overweight or obese body mass index (BMI). One of the important triggers of childhood obesity is the antibiotic use, which increases the adipogenesis and alters the microbiota composition (Li, Wang, et al., 2017). 
Table 1

Obesity Studies on Humans

\begin{tabular}{|c|c|c|c|c|}
\hline Study & No. of patients & Microbiota spp. & Outcome & $\begin{array}{c}\text { Influencel } \\
\text { modulation on/of } \\
\text { microbiota }\end{array}$ \\
\hline $\begin{array}{l}\text { Miller et al. } \\
(2017)\end{array}$ & $\begin{array}{c}355 \text { per- and } \\
\text { postmenopausal } \\
\text { women }\end{array}$ & & $\begin{array}{l}\text { ODMA non- } \\
\text { producer } \\
\text { phenotype }\end{array}$ & \\
\hline $\begin{array}{l}\text { Menni et al. } \\
\text { (2017) }\end{array}$ & $\begin{array}{c}1632 \\
\text { healthy females } \\
\text { (TwinsUK) }\end{array}$ & $\begin{array}{c}\text { Ruminococcaceae } \\
\text { Lachnospiraceae } \\
\text { Bacterioides }\end{array}$ & $\begin{array}{l}\text { high microbiome } \\
\text { diversity, high- } \\
\text { fibre intake and } \\
\text { OTUs }\end{array}$ & $\begin{array}{c}\text { 16S ribosomal } \\
\text { RNA gene } \\
\text { sequence }\end{array}$ \\
\hline $\begin{array}{l}\text { Bergeron et al. } \\
\text { (2016) }\end{array}$ & 52 & & $\begin{array}{c}\text { cardiovascular } \\
\text { risk }\end{array}$ & TMAO \\
\hline $\begin{array}{l}\text { Betancourt- } \\
\text { Garcia et al. } \\
(2017)\end{array}$ & NR & & NAFLD & \\
\hline $\begin{array}{l}\text { Davis et al. } \\
\text { (2017) }\end{array}$ & 81 & $\begin{array}{l}\text { Bacteroidetes- } \\
\text { Firmicutes ratio }\end{array}$ & Westernized diet & \\
\hline $\begin{array}{l}\text { Prescott } \\
(2016)\end{array}$ & NR & & early-nutrition & \\
\hline $\begin{array}{l}\text { Palleja et al. } \\
(2016)\end{array}$ & $\begin{array}{l}13 \text { morbid } \\
\text { obesity }\end{array}$ & $\begin{array}{l}\text { E. coli, Klebsiella } \\
\text { pneumoniae, } \\
\text { Veillonella spp., } \\
\text { Streptococcus } \\
\text { spp., Alistipes } \\
\text { spp., Akkermansia } \\
\text { muciniphila }\end{array}$ & $\begin{array}{l}\text { Roux-en-Y } \\
\text { gastric bypass }\end{array}$ & $\begin{array}{c}\text { microbiota } \\
\text { diversity increase }\end{array}$ \\
\hline $\begin{array}{l}\text { Mueller et al. } \\
(2016)\end{array}$ & 74 neonates & $\begin{array}{c}\text { Bacteroides } \\
\text { Enterococcus, } \\
\text { Acinetobacter, } \\
\text { Pseudomonas, } \\
\text { Hydrogenophilus }\end{array}$ & $\begin{array}{c}\text { vaginal vs. } \\
\text { Cesarean birth }\end{array}$ & \\
\hline $\begin{array}{l}\text { Mayorga } \\
\text { Reyes et al. } \\
(2016)\end{array}$ & young adults & $\begin{array}{c}\text { Bacteroides } \\
\text { thetaiotaomicron } \\
\text { Prevotella, } \\
\text { Faecalibacterium } \\
\text { prausnitzii, } \\
\text { Clostridium } \\
\text { leptum } \\
\text { Bifidobacterium } \\
\text { longum }\end{array}$ & $\begin{array}{l}\text { diet rich in } \\
\text { unsaturated fatty } \\
\text { acids and fibre }\end{array}$ & $\begin{array}{l}\text { high abundance } \\
\text { of } \mathrm{B} \text {. longum and } \\
\text { Bacteroidetes }\end{array}$ \\
\hline $\begin{array}{l}\text { Emoto et al. } \\
\text { (2016) }\end{array}$ & 119 & $\begin{array}{c}\text { high } \\
\text { Lactobacillales } \\
\text { low Bacteroidetes } \\
\text { (Bacteroides }+ \\
\text { Prevotella) }\end{array}$ & $\begin{array}{c}\text { coronary artery } \\
\text { disease }\end{array}$ & \\
\hline
\end{tabular}


Duca, I., Rusu, F., Chira, A., and Dumitrascu, D. L.:

Microbiota and Body Weight

\begin{tabular}{|c|c|c|c|c|}
\hline Study & No. of patients & Microbiota spp. & Outcome & $\begin{array}{c}\text { Influencel } \\
\text { modulation on/of } \\
\text { microbiota }\end{array}$ \\
\hline $\begin{array}{l}\text { Barczynska et } \\
\text { al. (2016) }\end{array}$ & 5 children & $\begin{array}{c}\text { Firmicutes, } \\
\text { Bacteroidetes, } \\
\text { Actinobacteria }\end{array}$ & fibre preparations & \\
\hline $\begin{array}{l}\text { Radilla- } \\
\text { Vázquez et al. } \\
\text { (2016) }\end{array}$ & $\begin{array}{l}64 \text { young } \\
\text { Mexicans }\end{array}$ & $\begin{array}{c}\text { Clostridum } \\
\text { leptum } \\
\text { Lactobacillus } \\
\text { Prevotella } \\
\text { Escherichia coli }\end{array}$ & endotoxemia & $\begin{array}{c}\text { body temperature } \\
\text { elevated }\end{array}$ \\
\hline $\begin{array}{l}\text { Moreno-Indias } \\
\text { et al. (2016) }\end{array}$ & NR & $\begin{array}{l}\text { bifidobacteria } \\
\text { Lactobacillus } \\
\text { F. prausnitzii } \\
\text { Roseburia } \\
\end{array}$ & $\begin{array}{l}\text { red wine } \\
\text { polyphenols }\end{array}$ & prebiotic \\
\hline $\begin{array}{l}\text { Ignacio et al. } \\
(2016)\end{array}$ & 84 children & $\begin{array}{c}\text { Bacteroides } \\
\text { fragilis } \\
\text { Clostridium } \\
\text { Bifidobacterium } \\
\text { Escherichia coli }\end{array}$ & $\begin{array}{l}\text { BMI-phyla } \\
\text { correlation }\end{array}$ & \\
\hline $\begin{array}{l}\text { Angelakis et } \\
\text { al. }(2015)\end{array}$ & 10 & $\begin{array}{c}\text { Firmicutes } \\
\text { Actinobacteria }\end{array}$ & $\begin{array}{l}\text { duodenal } \\
\text { microbiota }\end{array}$ & $\begin{array}{c}\text { anaerobiotic } \\
\text { genera }\end{array}$ \\
\hline $\begin{array}{l}\text { Kasai et al. } \\
(2015)\end{array}$ & 56 Japanese & $\begin{array}{c}\text { Blautia } \\
\text { hydrogenoto- } \\
\text { rophica } \\
\text { Coprococcus } \\
\text { catus } \\
\text { Eubacterium } \\
\text { ventriosum } \\
\text { Ruminococcus } \\
\text { bromii } \\
\text { Ruminococcus } \\
\text { obeum } \\
\end{array}$ & & $\begin{array}{c}\text { high Firmicutes/ } \\
\text { Bacteroidetes } \\
\text { ratio }\end{array}$ \\
\hline $\begin{array}{l}\text { Bernardi et al. } \\
\text { (2015) }\end{array}$ & $\begin{array}{c}2063 \text { young } \\
\text { Brazilian adults }\end{array}$ & & Cesarean delivery & BMI \\
\hline $\begin{array}{l}\text { De Lorenzo et } \\
\text { al. (2017) }\end{array}$ & 60 women & & psychobiotics & $\begin{array}{l}\text { SIBO, orocecal } \\
\text { transit time }\end{array}$ \\
\hline $\begin{array}{l}\text { Cassidy- } \\
\text { Bushrow et al. } \\
(2015)\end{array}$ & 639 & & $\begin{array}{l}\text { delivery mode- } \\
\text { BMI relationship }\end{array}$ & pets \\
\hline
\end{tabular}

Note . NR = not reported; ODMA = O-desmethylangolensin; OUT $=$ operational bacterial taxonomic units; IMAO = trimethylamine-N-oxide; MUFA = mono-unsaturated fatty acid; PUFA = polyunsaturated fatty acids.

Table 1 described human studies that concerned different types of species of microbiota and their change in children and adults, but also their impact on weight gain, diabetes mellitus and cardiovascular diseases. 
O-desmethylangolensin (ODMA) non-producer phenotype (individuals that are not capable of metabolizing the soy isoflavone daidzein to ODMA) was associated with obesity in peri- and post-menopausal women (Miller et al., 2017).

Non-alcoholic liver fatty disease (NAFLD) combined with portal vein toxins secondary to an altered microbiota led to early occurrence of non-alcoholic steatohepatitis (NASH) in children, through the following mechanisms: increasing obesity in children, gut-liver-axis-dysfunction, perturbations of trace element homeostasis, and oxidative stress due to genetic changes - allele substitution in the PNPLA3 gene (Betancourt-Garcia et al., 2017; Clemente, Mandato, Poeta, \& Vajro, 2016).

\section{Gut Changes in Pregnancy}

Excessive maternal pre-pregnancy weight associated with vaginal delivery leads to altered microbiota of the child and consequently an altered metabolism (Mueller et al., 2016). Cesarean delivery was associated with a higher BMI but there was no correlation found with glucose, insulin resistance, cholesterolemia and triglyceridemia levels in a Brazilian study (Bernardi et al., 2015). Caesarean sectionborn children without a pet animal at home had a higher risk of obesity at the age of 2 years, without knowing the exact mechanism (Cassidy-Bushrow et al., 2015). Higher risk of neurodevelopmental disorders in children, including autism, has been associated with maternal obesity during pregnancy (Buffington et al., 2016). Dietary strategies including early nutritional exposures, with more tolerogenic conditions during early immune programming in small children reduces the risk of allergies and many inflammatory diseases (Prescott, 2016).

\section{Gut Compositional Changes in Humans}

Ignacio et al. (2016) showed that lean individuals have higher abundance of Bifidobacterium spp. compared with obese persons. Rich diet in unsaturated fatty acids and fibre induces in young adults abundant beneficial microbiota population, like B.longum and Bacteroidetes (Mayorga Reyes et al., 2016). Predominance of Firmicutes and anaerobic genera over the Bacteroidetes and Actinobacteria strains were found in obese children (Angelakis et al., 2015; Barczynska, Slizewska, Litwin, Szalecki, \& Kapusniak, 2016). Central adiposity in young obese people had a corresponding subclinical endotoxemia (measured by serum lipopolysacharides concentration) with small amount of E.coli and hypertrygliceridemia (RadillaVázquez et al., 2016). Not only bacterial population is implied, but specific fungal composition of microbiota (mycobiome) was proven also to have importance in weight gain, Mucor racemosus and M. fuscus being more abundant in lean people (Mar Rodríguez et al., 2015). 


\section{Therapeutic Options}

High diversity of microbiota, together with fiber intake and operational bacterial taxonomic units (OTUs), like Ruminococcaceae and Lachnospiraceae, proved to be associated with lower risk of weight gain in humans, independently of the caloric intake (Menni et al., 2017). Moreno-Indias et al. (2016) showed that moderate intake of red wine improved weight gain. Recent studies revealed that intake of selected psychobiotics modulated microbiota in preobese and obese women, but further research is needed in order to establish exact correlations (De Lorenzo et al., 2017). For children and adults, fecal transplantation represents a new way of managing severe obesity (Jayasinghe, Chiavaroli, \& Holland, 2016).

Bariatric surgery represents the main option in morbid obesity. Gut microbioma diversity increased within the first 3 months after Roux-en-Y-gastric bypass surgery in obese patients, remaining high even one year later (Palleja et al., 2016).

\section{Implication of Microbiota in Obesity - Experimental Studies on Animals}

\section{Etiopathogenesis}

Noble et al. (2017) showed that especially early-life sugar consumption alters in rats the microbiota, independently of caloric intake, body weight or adiposity index. Artificial sweeteners, like saccharin and acesulfame-potassium disturbs the gut microbiota in mice inducing glucose intolerance, raising questions about their possible contribution to the epidemic of obesity and diabetes (Bian et al., 2017). Hypogonadism and androgen deprivation (castration) altered the cecal and fecal microbiota, increased plasma adiponectin irrespective of diet, and increased the risk factors for cardiovascular disease (obesity, impaired fasting glucose, high triglyceride amount in liver, muscle weight loss) in high-fat diet-fed mice (Harada, Hanaoka, Hanada, et al., 2016); testosterone deficiency altered the intestinal microbiome in mice, inducing abdominal obesity (Harada, Hanaoka, Horiuchi et al., 2016).

Table 2 described animals' experimental studies that concerned several types of species of microbiota and the change induced by different types of diet, but also the impact of pre/probiotics on weight gain and obesity reduction.

Experimental studies on mice showed that deficiency of intestinal mucin- 2 and higher IL-22 levels offer protection from diet-induced NAFL and obesity (Hartmann et al., 2016). In line with human studies, hypogonadism represents also in mice a responsible factor for inducing cardiovascular diseases (Harada, Hanaoka, Hanada et al., 2016). 
Table 2

Obesity Experimental Studies on Animals

\begin{tabular}{|c|c|c|c|c|c|}
\hline Study & Animal & $\begin{array}{l}\text { No. of } \\
\text { animals }\end{array}$ & Microbiota spp. & Outcome & $\begin{array}{c}\text { Influencel } \\
\text { modulation of } \\
\text { microbiota }\end{array}$ \\
\hline $\begin{array}{l}\text { Li, Lauber, et } \\
\text { al. (2017) }\end{array}$ & $\begin{array}{l}\text { mice } \\
\text { dogs }\end{array}$ & 63 & $\begin{array}{c}\text { Blautia bacteria } \\
\text { Desulfovibrio } \\
\text { bacteria } \\
\text { Cl. hiranonis, } \\
\text { Cl. perfringens, } \\
\text { Ruminococcus } \\
\text { gnavus }\end{array}$ & HPLC diet & $\begin{array}{c}\text { prebiotic } \\
\\
\text { decrease } \\
\text { Bacteroidetes/ } \\
\text { Firmicutes } \\
\text { increase } \\
\text { Bacteroides/ } \\
\text { Prevotella }\end{array}$ \\
\hline $\begin{array}{l}\text { McGavigan et } \\
\text { al. (2017) }\end{array}$ & mice & 14 & & $\begin{array}{l}\text { Vertical sleeve } \\
\text { gastrectomy }\end{array}$ & $\begin{array}{c}\text { incr. } \\
\text { Gammaproteo- } \\
\text { bacteria }+ \\
\text { Enterococcus, } \\
\text { decr. } \\
\text { Adlercreutzia }\end{array}$ \\
\hline $\begin{array}{l}\text { Noble et al. } \\
(2017)\end{array}$ & rats & 42 & $\begin{array}{c}\text { Prevotella } \\
\text { Lachnospiraceae } \\
\text { incertae sedis } \\
\text { Bacteroides } \\
\text { Alistipes } \\
\text { Lactobacillus } \\
\text { Cl. sensu stricto } \\
\text { Bifidobacteriaceae } \\
\text { Parasutterella } \\
\end{array}$ & $\begin{array}{l}\text { early life sugar } \\
\text { consumption }\end{array}$ & $\begin{array}{c}\text { alteration } \\
\text { independent of } \\
\text { caloric intake, } \\
\text { BMI }\end{array}$ \\
\hline $\begin{array}{l}\text { Wang et al. } \\
\text { (2016) }\end{array}$ & mice & NR & & $\begin{array}{c}\text { green tea } \\
\text { polyphenols }\end{array}$ & \\
\hline $\begin{array}{l}\text { Ansari et al. } \\
\text { (2017) }\end{array}$ & mice & 18 & $\begin{array}{l}\text { Bacteroidetes/ } \\
\text { Firmicutes ratio }\end{array}$ & $\begin{array}{c}\text { Chowiseungcheng } \\
\text {-tang (CST) }\end{array}$ & anti-obesity effect \\
\hline $\begin{array}{l}\text { Kieffer et al. } \\
\text { (2016) }\end{array}$ & mice & 29 & & $\begin{array}{l}\text { High-amylose- } \\
\text { maize resistant } \\
\text { starch type } 2 \\
\end{array}$ & incr. fecal nitrogen \\
\hline $\begin{array}{l}\text { Harada, } \\
\text { Hanaoka, } \\
\text { Hanada, et al. } \\
(2016)\end{array}$ & mice & 29 & $\begin{array}{c}\text { Firmicutes/ } \\
\text { Bacteroidetes ratio } \\
\text { Lactobacillus }\end{array}$ & $\begin{array}{l}\text { hypogonadism, } \\
\text { high CV risk }\end{array}$ & \\
\hline $\begin{array}{l}\text { Tung et al. } \\
\text { (2016) }\end{array}$ & mice & NR & & Piceatannol & anti-obesity effect \\
\hline $\begin{array}{l}\text { Yan et al. } \\
(2016)\end{array}$ & rats & 15 & $\begin{array}{c}\text { Lactobacillus, } \\
\text { Bifidobacterium, } \\
\text { Tenericutes, } \\
\text { Ruminococcaceae }\end{array}$ & $\begin{array}{c}\text { sitagliptin; } \\
\text { anti-diabetic effect }\end{array}$ & $\begin{array}{l}\text { correction of } \\
\text { dysbiosis }\end{array}$ \\
\hline
\end{tabular}


Duca, I., Rusu, F., Chira, A., and Dumitrascu, D. L.:

Microbiota and Body Weight

\begin{tabular}{|c|c|c|c|c|c|}
\hline Study & Animal & $\begin{array}{l}\text { No. of } \\
\text { animals }\end{array}$ & Microbiota spp. & Outcome & $\begin{array}{c}\text { Influencel } \\
\text { modulation of } \\
\text { microbiota }\end{array}$ \\
\hline $\begin{array}{l}\text { Basso et al. } \\
\text { (2016) }\end{array}$ & rats & 60 & $\begin{array}{c}\text { low } \\
\text { Ruminococcus } \\
\text { high } \\
\text { Lactobacillus+ } \\
\text { Collinsella } \\
\end{array}$ & $\begin{array}{l}\text { glandular } \\
\text { gastrectomy }\end{array}$ & remodelling \\
\hline $\begin{array}{l}\text { Perry et al. } \\
(2016)\end{array}$ & mice & NR & & $\begin{array}{c}\text { acetate production, } \\
\text { parasympath. } \\
\text { activation }\end{array}$ & \\
\hline $\begin{array}{l}\text { Wang et al. } \\
\text { (2016) }\end{array}$ & mice & 48 & & \begin{tabular}{|c|} 
accelarated \\
postna \\
neonatal growth
\end{tabular} & $\begin{array}{l}\text { increased risk for } \\
\text { adult MS }\end{array}$ \\
\hline Oh et al. (2016) & rats & NR & $\begin{array}{l}\text { Gammaproteo- } \\
\text { bacteria }\end{array}$ & $\begin{array}{c}\text { ileal transposition } \\
\text { surgery }\end{array}$ & \\
\hline $\begin{array}{l}\text { Park et al. } \\
\text { (2015) }\end{array}$ & dogs & 14 & Proteobacteria & $\begin{array}{l}\text { leptin, } \\
\text { adiponectin, low } \\
\text { serotonin }\end{array}$ & \\
\hline $\begin{array}{l}\text { Li, Wang, et al. } \\
\text { (2017) }\end{array}$ & mice & 30 & $\begin{array}{l}\text { high Firmicutes } \\
\text { /Bacteroidetes }\end{array}$ & $\begin{array}{l}\text { florfenicol and } \\
\text { azithromycin }\end{array}$ & \\
\hline $\begin{array}{l}\text { Welly et al. } \\
(2016)\end{array}$ & rats & 30 & $\begin{array}{c}\text { Streptococcaceae, } \\
\text { Rikenellacea }\end{array}$ & exercise vs. diet & \\
\hline $\begin{array}{l}\text { Harada, } \\
\text { Hanaoka, } \\
\text { Hanada, et al. } \\
(2016)\end{array}$ & mice & NR & $\begin{array}{c}\text { Firmicutes/ } \\
\text { Bacteroidetes, } \\
\text { Lactobacillus }\end{array}$ & castration & \\
\hline $\begin{array}{l}\text { Jiang et al. } \\
(2016)\end{array}$ & rats & 40 & $\begin{array}{c}\text { Bacteroidetes } \\
\text { Firmicutes }\end{array}$ & $\begin{array}{l}\text { apple-derived } \\
\text { pectin }\end{array}$ & \\
\hline $\begin{array}{l}\text { Garcia- } \\
\text { Mazcorro et al. } \\
(2016)\end{array}$ & mice & 21 & $\begin{array}{l}\text { Ruminococcaceae } \\
\text { Lactobacillus spp }\end{array}$ & $\begin{array}{l}\text { whole-wheat } \\
\text { consumption }\end{array}$ & \\
\hline $\begin{array}{l}\text { Gooda Sahib } \\
\text { Jambocus et al. } \\
(2016)\end{array}$ & rats & 36 & & $\begin{array}{l}\text { Morinda citrifolia } \\
\text { L. Leaf Extract }\end{array}$ & anti-obesity \\
\hline $\begin{array}{l}\text { Rajpal et al. } \\
(2015)\end{array}$ & mice & 30 & $\begin{array}{l}\text { Bacteroidetes } \\
\text { Firmicutes }\end{array}$ & $\begin{array}{l}\text { ceftazidime, } \\
\text { vancomycin }\end{array}$ & \\
\hline $\begin{array}{l}\text { Yadav et al. } \\
(2016)\end{array}$ & mice & 18 & & viral fecal content & \\
\hline $\begin{array}{l}\text { Cluny et al. } \\
(2015)\end{array}$ & mice & 32 & $\begin{array}{l}\text { Methanobrevi- } \\
\text { bacter spp }\end{array}$ & $\begin{array}{c}\text { Tetrahydrocanna- } \\
\text { binol }\end{array}$ & \\
\hline Xie et al. (2015) & rats & NR & $\begin{array}{l}\text { Lactobacillus } \\
\text { Enterococci }\end{array}$ & $\begin{array}{c}\text { Ligustrum } \\
\text { robustum }\end{array}$ & anti-obesity \\
\hline $\begin{array}{l}\text { Zhang et al. } \\
\text { (2015) }\end{array}$ & rats & 134 & & $\begin{array}{l}\text { berberine and } \\
\text { metformin }\end{array}$ & $\begin{array}{l}\text { decr. microb. } \\
\text { diversity }\end{array}$ \\
\hline $\begin{array}{l}\text { Paul et al. } \\
(2016)\end{array}$ & rats & 104 & $\begin{array}{l}\text { Bifidobacterium } \\
\text { Clostridium }\end{array}$ & prebiotics & $\begin{array}{l}\text { pregnancy, } \\
\text { lactation }\end{array}$ \\
\hline $\begin{array}{l}\text { Chaplin et al. } \\
(2016)\end{array}$ & mice & NR & & calcium- prebiotic & \\
\hline
\end{tabular}


PSYCHOLOGICAL TOPICS, 27 (2018), 1, 33-53

\begin{tabular}{|c|c|c|c|c|c|}
\hline Study & Animal & $\begin{array}{c}\text { No. of } \\
\text { animals }\end{array}$ & Microbiota spp. & Outcome & $\begin{array}{c}\text { Influencel } \\
\text { modulation of } \\
\text { microbiota }\end{array}$ \\
\hline $\begin{array}{l}\text { Hartmann et al. } \\
\text { (2016) }\end{array}$ & mice & NR & & intestinal mucin-2 & NAFLD \\
\hline $\begin{array}{l}\text { Schneeberger et } \\
\text { al. (2015) }\end{array}$ & mice & 46 & $\begin{array}{c}\text { Akkermansia } \\
\text { muciniphila }\end{array}$ & & \\
\hline $\begin{array}{l}\text { Garidou et al. } \\
\text { (2015) }\end{array}$ & mice & NR & & ileum microbiota & \\
\hline $\begin{array}{l}\text { Chang et al. } \\
(2015)\end{array}$ & mice & 25 & $\begin{array}{c}\text { Firmicutes/ } \\
\text { Bacteroidetes }\end{array}$ & $\begin{array}{c}\text { Ganoderma } \\
\text { lucidum }\end{array}$ & prebiotic \\
\hline $\begin{array}{l}\text { Bruce-Keller et } \\
\text { al. (2015) }\end{array}$ & mice & 30 & & $\begin{array}{l}\text { dementia, } \\
\text { depression }\end{array}$ & \\
\hline $\begin{array}{l}\text { Bian et al. } \\
\text { (2017) }\end{array}$ & mice & 20 & & saccharin & \\
\hline $\begin{array}{l}\text { Kang et al. } \\
(2017)\end{array}$ & mice & 24 & & chilli pepper & \\
\hline $\begin{array}{l}\text { Li, Wang, et al. } \\
\text { (2017) }\end{array}$ & mice & NR & Rikenella & $\begin{array}{c}\text { florfenicol, } \\
\text { azithromycin }\end{array}$ & \\
\hline $\begin{array}{l}\text { Kulecka et al. } \\
\text { (2016) }\end{array}$ & rats & 64 & & fecal transplant & \\
\hline
\end{tabular}

Note $. \mathrm{NR}=$ not reported; $\mathrm{MS}=$ metabolic syndrome.

\section{Gut Composition Changes in Animals}

Greater abundance of Firmicutes and lower of Bacteroidetes, decreased Bacteroidetes/Firmicutes ratio and increased Bacteroides/Prevotella ratio were found in high-protein, low-carbohydrate (HPLC) diet-fed dogs; microbial gene networks were enriched by using HPLC diet, maintaining weight in dogs (Li, Lauber, Czarnecki-Maulden, Pan, \& Hannah, 2017). Another beneficial bacteria, implied in metabolism, is Akkermansia muciniphila; its abundance is affected by age and highfat diet (Schneeberger et al., 2015). It was proven that obese subjects have an increased viral fecal population (Yadav, Jain, \& Nagpal, 2016).

\section{Therapeutic Options}

Many substances targeting the microbiota, like probiotics (live bacteria), prebiotics (oligosaccharides) and synbiotics (pre- and probiotics) have been found to have the capability of acting in order to prevent/treat obesity (Kieffer et al., 2016).

Studies on mice proved that Berberine, a Chinese herb, has lipid lowering effect, through several mechanisms: inhibition of bile salt hydrolase activity, increasing the taurocholic-acid, activation of intestinal farnesoid-X receptor and reduction of longchain-fatty acid-uptake in the liver (Ziętak, Chabowska-Kita, \& Kozak, 2017). Beneficial effects, obtained in rats by reduction of microbial diversity of the host, can be achieved by administration of Berberine in combination with Metformin (Zhang 
et al., 2015). Among prebiotics, dietary lipid absorbent-montmorillonite (DLA-M) seems to prevent dysbiosis and obesity-related metabolic disorders by absorbing free fatty acids and endotoxins (Xu et al., 2017). Another prebiotic, the Chinese mushroom with anti-diabetic effect, Ganoderma lucidum, reduced obesity, inflammation in high-fat diet fed mice (Chang et al., 2015). Polyphenols from green tea (Wang, Zeng, et al., 2016) improved metabolic syndrome markers in mice, such as: reduced weight gain, adipocyte hypertrophy and liver steatosis in a dosedependent manner, increasing the number of butyrate-producing bacteria (Faecalibacterium prausnitzii, Roseburia), Bifidobacteria and Lactobacillus, acting as a prebiotic. A significant reduction of body and liver weight, glucose levels and dyslipidemia (total cholesterol, LDL and HDL-chlolesterol) was achieved in mice by using piceatannol, an analog of resveratrol (Tung et al., 2016). Herb formulas, like Chowiseungcheng-tang (CST) have anti-obesity effect by modulating the metabolism-related neuropeptides, adipokines and microbiota composition in mice (Ansari et al., 2016). Yan et al. showed that intestinal flora changed after oral gavageadministration of Sitagliptin in rats, leading to improvement of glucose metabolism and moderate correction of dysbiosis in T2DM (Yan, Feng, Li, Tang, \& Wang, 2016). Exercise vs. diet alone improved in rats the insulin resistance, reduced LDLcholesterol and significantly increased the abundance of cecal Streptococcaceae, having a weight-loss independent metabolic benefit (Welly et al., 2016). Improvement of metabolic endotoxemia, weight, steatosis and insulin resistance was achieved also by apple-derived pectin supplementation in diet-induced obese rats (Jiang et al., 2016) and by red pitaya fruit (Hylocereus polyrhizus) betacianins in mice (Song et al., 2016). Experimental studies on rats, showed that administration of Morinda citrifolia L. leaves extract had significant anti-obesity effect after 9 weeks of treatment (Gooda Sahib Jambocus et al., 2016). Composition and diversity of microbiota suffered beneficial changes in obesity control, both in vivo and in vitro, by administration of Ligustrum robustum in high-fat diet rats (Xie et al., 2015). Certain antibiotics, like Ceftazidime, improved the metabolic variables (glucose, insulin, glucagon-like peptide-1) in a dose-dependent manner in obese mice (Rajpal et al., 2015); co-administration of azithromycin with intestinal alkaline phosphatase early in life prevented the development of metabolic syndrome (Economopoulos et al., 2016). Similar to the frequent cannabis users, it was proven that chronic administration of Tetrahydrocannabiol reduced weight gain and fat mas gain in dietinduced obese mice (Cluny, Keenan, Reimer, Le Foll, \& Sharkey, 2015). Calcium supplementation acted also in a prebiotic manner on microbiota in obese mice (Chaplin, Parra, Laraichi, Serra, \& Palou, 2016). Treatment of Helicobacter pylori infection, although the exact mechanism of action is not known yet, had a benefic effect on insulin resistance in mice (He et al., 2016). Dietary capsaicine, the major pungent bioactivator in chili peppers, prevents dysbiosis, having anti-obesity effect in mice (Kang et al., 2017). Prebiotic intake during lactation and pregnancy in obese mothers improves the metabolic profile of the offspring in rats (Paul, Bomhof, \& 
Vogel, 2016). Fecal transplant from obese to lean mice led in the latter to adopting the obese phenotype (Kulecka et al., 2016).

Improvement of insulin resistance has been achieved in rats by glandular gastrectomy (resection of $80 \%$ of the glandular portion), even if obesity persists (Basso et al., 2016). Among the surgical variants of bariatric treatment, ileal transposition surgery showed obvious improvement of weight loss, glucose tolerance, increased insulin sensitivity, being a revolutionary method for obesity and T2DM (Oh et al., 2016). Vertical sleeve gastrectomy-induced reduction in blood pressure in mice shifts in gut microbiotal population, by inducing increases in the relative abundance of Gammaproteobacteria and Enterococcus and decreasing Adlercreutzia (McGavigan et al., 2017).

\section{Discussion}

Although other reviews have already searched for possible correlations between microbiota and obesity, the distinct character of our review is that it comprises not only recent studies in human (including small children and pregnant women) and animal models but also therapeutic methods of treating weight gain.

The appearance of obesity, T2DM and atherosclerosis is influenced by the intestinal mircrobiota (Wegielska \& Suliburska, 2016). Alteration of microbiota is linked with a high incidence of coronary artery disease (Emoto et al., 2016); biomarkers of cardiovascular risk, like TMAO (trimethylamine-N-oxide) are dependent on microbiota (Bergeron et al., 2016). Association of dysbiosis, obesity and diabetes is also a higher risk of osteoporosis (Ejtahed, Soroush, Angoorani, Larijani, \& Hasani-Ranjbar, 2016) and asthma (obesity-related asthma by alteration of both gastrointestinal and lung microbiota) (Cho \& Shore, 2016). Dysbiosis has been recently demonstrated to have a role in the development and progression of kidney disease in obese people, so pre- and probiotics were shown in some studies to have benefits in improving the kidney injury (Wanchai et al., 2017).

Alterations in the composition of microbiota can be caused by different agents like: industrialized food (especially higher fried food intake), combined with use of antibiotics, low-fiber-diets, especially lack of soluble fiber (inulin), low-bacteria diets (Zschocke, 2016). There have been controversies regarding azithromycin use: early abusive antibiotic exposure in childhood represents a damage of microbiota, increasing the adipogenesis ( $\mathrm{Li}$, Wang, et al., 2017); on the other hand, targeted use of simultaneous administration of azithromycin with intestinal alkaline phosphatase early in life prevents the development of metabolic syndrome (Economopoulos et al., 2016). So healthy high-fiber diet, well established meal rhythms and strategic intake of bacteria could reestablish the microbiota balance. Early onset of obesity increases the risk of obesity in adulthood. 
Mechanisms that are involved in microbiota changes in obesity are following: chronic inflammation, activation of TLR4, insulin resistance, effects on bile acids, branched-chain amino acids (Saad, Santos, \& Prada, 2016), decreased 5HT levels (increasing appetite) (Park et al., 2015), gastrointestinal vagal signaling (Kentish \& Page, 2015). Pathogenesis of obesity implies changes regarding molecular mechanisms, including hormones like: glucagon like peptide-1, pancreatic polypeptide, increased ghrelin secretion (Basso et al., 2016; Perry et al., 2016) and cholecystokinin (Mishra, Dubey, \& Ghosh, 2016). The ileal microbiota was proven in a study by Garidou et al. to give the outcome of metabolic disease by regulating Th17 cell homeostasis (Garidou et al., 2015). Another role was attributed to the brown fat based thermogenesis, in order to stimulate energy expenditure to reduce obesity (Ziętak et al., 2017). Accelerated postnatal growth in low birth-weight humans, with dysbiotic microbiome, leads to a higher risk of metabolic syndrome in adulthood than in normal birth-weight individuals (Wang, Tang, et al., 2016).

During pregnancy, significant changes inside the microbiome take place, therefore alterations at this level are important to be avoided in order to have a healthy pregnancy (Neuman \& Koren, 2017).

It has been noticed that there are quantitative and qualitative compositional differences regarding gut microbiota in obese patients and healthy people; the latter proved to have higher abundance of Bifidobacterium spp. compared with overweight persons (Ignacio et al., 2016), while obese subjects have reduced numbers of Bacteroidetes and increased numbers of Firmicutes compared to lean people.

Controversies regarding the implication of diversity of intestinal microbiota in weight gain and obesity appeared between studies on humans and animals: lower diversity of microbial species was shown by Park et al in a study on obese beagle dogs (Park et al., 2015), while another study proved by terminal restriction fragment length polymorphism a greater bacterial diversity and a specific composition (Blautia hydogenotrophica, Coprococcus catus, Ruminococcus bromii, Eubacterium ventriosum) in obese Japanese patients (Kasai et al., 2015).

Experimental studies on humans and animals revealed discrepancy regarding implication of Lactobacillus spp. in weight induction: higher abundance of Lactobacillus spp. in mice was associated with whole-wheat consumption, vs. lean and obese mice with standard diet (Garcia-Mazcorro, Ivanov, Mills, \& Noratto, 2016); on the other hand, Ignacio et al. showed that Lactobacillus spp. were in higher number $(p=.02)$ in obese and overweight children compared to the lean ones (Ignacio et al., 2016).

Regarding effective strategies in order to lose weight, HPLC diets have proved to be for many years effective ( $\mathrm{Li}$, Lauber, et al., 2017), and personalized dietary treatments represent the future aim (Goni, Cuervo, Milagro, \& Martínez, 2016). Many herbs proved to have prebiotic effect in order to prevent and even reduce obesity, physical exercise had a weight-loss independent metabolic benefit vs. diet, and last, but not least the bariatric surgery should be taken into account with its 
positive results both on microbioal composition and weight loss changes. Antiviral agents and mycobiome manipulation would represent a new target in the therapy of obesity (Mar Rodríguez et al., 2015).

High dietary polyphenol intake included in Mediterranean diet, induces a low risk for neurodegenerative diseases, DM, CV diseases, hypertension, obesity and early death (Anderson \& Nieman, 2016). Parasympathetic activation can be a therapeutic option for obesity (Perry et al., 2016). Regular coffee consumption (3-4 cups/day) proved to reduce the risk of developing T2DM, due to caffeine and chlorogenic acid content (Santos \& Lima, 2016). Gallagher and LeRoith (2015) showed, that intentional weight loss protects against carcinogenesis, and antidiabetic therapy may be effective in cancer progression.

In conclusion, implication of weight gain, obesity and gut microbiota represent a bidirectional effect. Any change of the quantitative and qualitative composition of microbiota has influence on the components of metabolic syndrome, therefore any management strategy for treating or preventing obesity in children and adulthood should have the microbiome as target. Any imbalance of microbiota composition, even starting from delivery mode, food diversification in children and weight gain in early years of life, have been proved to affect the adult's homeostasis, leading to obesity, and other metabolic diseases. Personalized diets, avoidance of antibiotic abuse, physical exercise and prebiotics would represent the most important options for the prophylaxis of obesity.

\section{References}

Anderson, J. J., \& Nieman, D. C. (2016). Diet quality-The Greeks had it right! Nutrients, $8(10), 636$.

Angelakis, E., Armougom, F., Carrière, F., Bachar, D., Laugier, R., Lagier, J. C., ... Raoult, D. (2015). A metagenomic investigation of the duodenal microbiota reveals links with obesity. PLoS One, 10(9), e0137784.

Ansari, A., Bose, S., Yadav, M. K., Wang, J. H., Song, Y. K., Ko, S. G., \& Kim, H. (2016). CST, an herbal formula, exerts anti-obesity effects through brain-gut-adipose tissue axis modulation in high-fat diet fed mice. Molecules, 21(12), 1750.

Barczynska, R., Slizewska, K., Litwin, M., Szalecki, M., \& Kapusniak, J. (2016). Effects of dietary fiber preparations made from maize starch on the growth and activity of selected bacteria from the Firmicutes, Bacteroidetes, and Actinobacteria phyla in fecal samples from obese children. Acta Biochimica Polonica, 63(2), 261-266.

Basso, N., Soricelli, E., Castagneto-Gissey, L., Casella, G., Albanese, D., Fava, F., ... Mingrone, G. (2016). Insulin resistance, microbiota, and fat distribution changes by a new model of vertical sleeve gastrectomy in obese rats. Diabetes, 65(10), 2990-3001. 
Bergeron, N., Williams, P. T., Lamendella, R., Faghihnia, N., Grube, A., Li, X., ... Krauss, R. M. (2016). Diets high in resistant starch increase plasma levels of trimethylamine-Noxide, a gut microbiome metabolite associated with CVD risk. British Journal of Nutrition, 116(12), 2020-2029.

Bernardi, J., Pinheiro, T. V., Mueller, N. T., Goldani, H. A., Gutierrez, M. R., Bettiol, H., ... Goldani, M. Z. (2015). Cesarean delivery and metabolic risk factors in young adults: A Brazilian birth cohort study. American Journal of Clinical Nutrition, 102(2), 295-301.

Betancourt-Garcia, M. M., Arguelles, A., Montes, J., Hernandez, A., Singh, M., \& Forse, R. A. (2017). Pediatric nonalcoholic fatty liver disease: The rise of a lethal disease among Mexican American Hispanic children. Obesity Surgery, 27(1), 236-244.

Bian, X., Chi, L., Gao, B., Tu, P., Ru, H., \& Lu, K. (2017). The artificial sweetener acesulfame potassium affects the gut microbiome and body weight gain in CD-1 mice. PLoS One, 12(6), e0178426.

Bruce-Keller, A. J., Salbaum, J. M., Luo, M., Blanchard, E., Taylor, C. M., Welsh, D. A., \& Berthoud H. R. (2015). Obese-type gut microbiota induce neurobehavioral changes in the absence of obesity. Biological Psychiatry, 77(7), 607-615.

Buffington, S. A., Di Prisco, G. V., Auchtung, T. A., Ajami, N. J., Petrosino, J. F., \& CostaMattioli, M. (2016). Microbial reconstitution reverses maternal diet-induced social and synaptic deficits in offspring. Cell, 165(7), 1762-1775.

Cassidy-Bushrow, A. E., Wegienka, G., Havstad, S., Levin, A. M., Lynch, S. V., Ownby, D. R., ... Johnson, C. C. (2015). Does pet-keeping modify the association of delivery mode with offspring body size? Maternal and Child Health Journal, 19(6), 1426-1433.

Chang, C. J., Lin, C. S., Lu, C. C., Martel, J., Ko, Y. F., Ojcius, D. M., ... Lai, H. C. (2015). Ganoderma lucidum reduces obesity in mice by modulating the composition of the gut microbiota. Nature Communications, 6, 7489.

Chaplin, A., Parra, P., Laraichi, S., Serra, F., \& Palou, A. (2016). Calcium supplementation modulates gut microbiota in a prebiotic manner in dietary obese mice. Molecular Nutrition \& Food Research, 60(2), 468-480.

Cho, Y., \& Shore, S. A. (2016). Obesity, Asthma, and the Microbiome. Physiology, 31(2), 108-116.

Clemente, M. G., Mandato, C., Poeta, M., \& Vajro, P. (2016). Pediatric non-alcoholic fatty liver disease: Recent solutions, unresolved issues, and future research directions. World Journal of Gastroenterology, 22(36), 8078-8093.

Cluny, N. L., Keenan, C. M., Reimer, R. A., Le Foll, B., \& Sharkey, K. A. (2015). Prevention of diet-induced obesity effects on body weight and gut microbiota in mice treated chronically with $\Delta$ 9-Tetrahydrocannabinol. PLoS One, 10(12), e0144270.

Davis, S. C., Yadav, J. S., Barrow, S. D., \& Robertson, B. K. (2017). Gut microbiome diversity influenced more by the Westernized dietary regime than the body mass index as assessed using effect size statistic. Microbiology, 6(4). doi:10.1002/mbo3.476 
De Lorenzo, A., Costacurta, M., Merra, G., Gualtieri, P., Cioccoloni, G., \& Marchetti, M., ... Di Renzo, L. (2017). Can psychobiotics intake modulate psychological profile and body composition of women affected by normal weight obese syndrome and obesity? A double blind randomized clinical trial. Journal of Translational Medicine, 15(1), 135.

Economopoulos, K. P., Ward, N. L., Phillips, C. D., Teshager, A., Patel, P., \& Mohamed, M., ... Hodin, R. A. (2016). Prevention of antibiotic-associated metabolic syndrome in mice by intestinal alkaline phosphatase. Diabetes, Obesity and Metabolism, 18(5), 519-527.

Ejtahed, H. S., Soroush, A. R., Angoorani, P., Larijani, B., \& Hasani-Ranjbar, S. (2016). Gut microbiota as a target in the pathogenesis of metabolic disorders: A new approach to novel therapeutic agents. Hormone and Metabolic Research, 48(6), 349-358.

Emoto, T., Yamashita, T., Sasaki, N., Hirota, Y., Hayashi, T., So, A., ... Hirata, K. (2016). Analysis of gut microbiota in coronary artery disease patients: A possible link between gut microbiota and coronary artery disease. Journal of Atherosclerosis and Thrombosis, 23(8), 908-921.

Gallagher, E. J., \& LeRoith, D. (2015). Obesity and diabetes: The increased risk of cancer and cancer-related mortality. Physiological Reviews, 95(3), 727-748.

Garcia-Mazcorro, J. F., Ivanov, I., Mills, D. A., \& Noratto, G. (2016). Influence of wholewheat consumption on fecal microbial community structure of obese diabetic mice. PeerJ, 4, e1702.

Garidou, L., Pomié, C., Klopp, P., Waget, A., Charpentier, J., Aloulou, M., ... Burcelin, R. (2015). The gut microbiota regulates intestinal CD4 T cells expressing ROR $\gamma \mathrm{t}$ and controls metabolic disease. Cell Metabolism, 22(1), 100-112.

Ghazalpour, A., Cespedes, I., Bennett, B. J., \& Allayee, H. (2016). Expanding role of gut microbiota in lipid metabolism. Current Opinion in Lipidology, 27(2), 141-147.

Goni, L., Cuervo, M., Milagro, F. I., \& Martínez, J. A. (2016). Future perspectives of personalized weight loss interventions based on nutrigenetic, epigenetic, and metagenomic data. Journal of Nutrition, 146(4), 905S-912S.

Gooda Sahib Jambocus, N., Saari, N., Ismail, A., Khatib, A., Mahomoodally, M. F., \& Abdul Hamid, A. (2016). An investigation into the antiobesity effects of morinda citrifolia 1. leaf extract in high fat diet induced obese rats using a 1H NMR metabolomics approach. Journal of Diabetes Research, 2391592.

Harada, N., Hanaoka, R., Hanada, K., Izawa, T., Inui, H., \& Yamaji, R. (2016). Hypogonadism alters cecal and fecal microbiota in male mice. Gut Microbes, 7(6), 533539.

Harada, N., Hanaoka, R., Horiuchi, H., Kitakaze, T., Mitani, T., Inui, H., \& Yamaji, R. (2016). Castration influences intestinal microflora and induces abdominal obesity in high-fat diet-fed mice. Scientific Reports, 6, 23001. 
Hartmann, P., Seebauer, C. T., Mazagova, M., Horvath, A., Wang, L., Llorente, C., ... Schnabl, B. (2016). Deficiency of intestinal mucin-2 protects mice from diet-induced fatty liver disease and obesity. American Journal of Physiology-Gastrointestinal and Liver Physiology, 310(5), G310-22.

He, C., Yang, Z., Cheng, D., Xie, C., Zhu, Y., Ge, Z., ... Lua, N. (2016). Helicobacter pylori infection aggravates diet-induced insulin resistance in association with gut microbiota of mice. EBioMedicin, 12, 247-254.

Ignacio, A., Fernandes, M. R., Rodrigues, V. A., Groppo, F. C., Cardoso, A. L., AvilaCampos, M. J., \& Nakano, V. (2016). Correlation between body mass index and faecal microbiota from children. Clinical Microbiology and Infection, 22(3), 258, e1-8.

Jayasinghe, T. N., Chiavaroli, V., \& Holland, D. J. (2016). The new era of treatment for obesity and metabolic disorders: Evidence and expectations for gut microbiome transplantation. Frontiers in Cellular and Infection Microbiology, 6(15), 1-11.

Jiang, T., Gao, X., Wu, C., Tian, F., Lei, Q., Bi, J., ... Wang, X. (2016). Apple-derived pectin modulates gut microbiota, improves gut barrier function, and attenuates metabolic endotoxemia in rats with diet-induced obesity. Nutrients, 8(3), 126.

Kang, C., Wang, B., Kaliannan, K., Wang, X., Lang, H., Hui, S., ... Mi, M. (2017). Gut microbiota mediates the protective effects of dietary capsaicin against chronic low-grade inflammation and associated obesity induced by high-fat diet. mBio, 8(4), e00900-17.

Kasai, C., Sugimoto, K., Moritani, I., Tanaka, J., Oya, Y., Inoue, H., ... Takase, K. (2015). Comparison of the gut microbiota composition between obese and non-obese individuals in a Japanese population, as analyzed by terminal restriction fragment length polymorphism and next-generation sequencing. BMC Gastroenterology, 15, 100.

Kentish, S. J., \& Page, A. J. (2015). The role of gastrointestinal vagal afferent fibres in obesity. Journal of Physiology, 593(4), 775-786.

Kieffer D. A., Piccolo, B. D., Marco, M. L., Kim, E. B., Goodson, M. L., Keenan, M. J., ... Adams, S. H. (2016). Obese mice fed a diet supplemented with enzyme-treated wheat bran display marked shifts in the liver metabolome concurrent with altered gut bacteria. Journal of Nutrition, 146(12), 2445-2460.

Koh, J. C., Loo, W. M., Goh, K. L., Sugano, K., Chan, W. K., Chiu, W. Y., ... Dan, Y. Y. (2016). Asian consensus on the relationship between obesity and gastrointestinal and liver diseases. Journal of Gastroenterology and Hepatology, 31(8), 1405-1413.

Kulecka, M., Paziewska, A., Zeber-Lubecka, N., Ambrozkiewicz, F., Kopczynski, M., Kuklinska, U., ... Ostrowski, J. (2016). Prolonged transfer of feces from the lean mice modulates gut microbiota in obese mice. Nutrition \& Metabolism, 13(1), 57.

Li, Q., Lauber, C. L., Czarnecki-Maulden, G., Pan, Y., \& Hannah, S. S. (2017). Effects of the dietary protein and carbohydrate ratio on gut microbiomes in dogs of different body conditions. mBio, 8(1), e01703-16. 
Li, R., Wang, H., Shi, Q., Wang, N., Zhang, Z., Xiong, C., ... Jiang, Q. (2017). Effects of oral florfenicol and azithromycin on gut microbiota and adipogenesis in mice. PLoS One, 12(7), e0181690.

Mar Rodríguez, M., Pérez, D., Javier Chaves, F., Esteve, E., Marin-Garcia, P., Xifra, G., ... Fernández Real, J. M. (2015). Obesity changes the human gut mycobiome. Scientific Reports, 5, 14600.

Mayorga Reyes, L., González Vázquez, R., Cruz Arroyo, S. M., Melendez Avalos, A., Reyes Castillo, P. A., Chavaro Pérez, D. A., ... Azaola Espinosa, A. (2016). Correlation between diet and gut bacteria in a population of young adults. International Journal of Food Sciences and Nutrition, 67(4), 470-478.

McGavigan, A. K., Henseler, Z. M., Garibay, D., Butler, S. D., Jayasinghe, S., Ley, R. E., ... Cummings, B. P. (2017). Vertical sleeve gastrectomy reduces blood pressure and hypothalamic endoplasmic reticulum stress in mice. Disease Models \& Mechanisms, 10(3), 235-243.

Menni, C., Jackson, M. A., Pallister, T., Steves, C. J., Spector, T. D., \& Valdes, A. M. (2017). Gut microbiome diversity and high-fibre intake are related to lower long-term weight gain. International Journal of Obesity, 41(7), 1099-1105.

Miller, L. M., Lampe, J. W., Newton, K. M., Gundersen, G., Fuller, S., Reed, S. D., \& Frankenfeld, C. L. (2017). Being overweight or obese is associated with harboring a gut microbial community not capable of metabolizing the soy isoflavone daidzein to $\mathrm{O}$ desmethylangolensin in peri- and post-menopausal women. Maturitas, 99, 37-42.

Mishra, A. K., Dubey, V., \& Ghosh, A. R. (2016). Obesity: An overview of possible role(s) of gut hormones, lipid sensing and gut microbiota. Metabolism, 65(1), 48-65.

Moreno-Indias, I., Sánchez-Alcoholado, L., Pérez-Martínez, P., Andrés-Lacueva, C., Cardona, F., Tinahones, F., \& Queipo-Ortuño, M. I. (2016). Red wine polyphenols modulate fecal microbiota and reduce markers of the metabolic syndrome in obese patients. Food \& Function, 7(4), 1775-1787.

Mueller, N. T., Shin, H., Pizoni, A., Werlang, I. C., Matte, U., Goldani, M. Z., ... DominguezBello, M. G. (2016). Birth mode-dependent association between pre-pregnancy maternal weight status and the neonatal intestinal microbiome. Scientific Reports, 6, 23133.

Nehra, V., Allen, J. M., Mailing, L. J., Kashyap, P. C., \& Woods, J. A. (2016). Gut microbiota: Modulation of host physiology in obesity. Physiology, 31(5), 327-335.

Neuman, H., \& Koren, O. (2017). The pregnancy microbiome. Nestle Nutrition Institute Workshop Series, 88, 1-9.

Noble, E. E., Hsu, T. M., Jones, R. B., Fodor, A. A., Goran, M. I., \& Kanoski, S. E. (2017). Early-life sugar consumption affects the rat microbiome independently of obesity. Journal of Nutrition, 147(1), 20-28.

Oh, T. J., Ahn, C. H., \& Cho, Y. M. (2016). Contribution of the distal small intestine to metabolic improvement after bariatric/metabolic surgery: Lessons from ileal transposition surgery. Journal of Diabetes Investigation, 7(Suppl 1), 94-101. 
Palleja, A., Kashani, A., Allin, K. H., Nielsen, T., Zhang, C., Li, Y., ... Arumugam, M. (2016). Roux-en-Y gastric bypass surgery of morbidly obese patients induces swift and persistent changes of the individual gut microbiota. Genome Medicine, 8(1), 67.

Park, H. J., Lee, S. E., Kim, H. B., Isaacson, R. E., Seo, K. W., \& Song, K. H. (2015). Association of obesity with serum leptin, adiponectin, and serotonin and gut microflora in beagle dogs. Journal of Veterinary Internal Medicine, 29(1), 43-50.

Paul, H. A., Bomhof, M. R., \& Vogel, H. J. (2016). Diet-induced changes in maternal ghut microbiota and metabolomic profiles influence programming of offspring obesity risk in rats. Scientific Reports, 12(6), 20683, 1-14.

Perry, R. J., Peng, L., Barry, N. A., Cline, G. W., Zhang, D., \& Cardone, R. L. (2016). Acetate mediates a microbiome-brain- $\beta$-cell axis to promote metabolic syndrome. Nature, 534(7606), 213-217.

Prescott, S. L. (2016). Early nutrition as a major determinant of 'immune health': Implications for allergy, obesity and other noncommunicable diseases. Nestle Nutrition Institute Workshop Series, 85, 1-17.

Radilla-Vázquez, R. B., Parra-Rojas, I., Martínez-Hernández, N. E., Márquez-Sandoval, Y. F., Illades-Aguiar, B., \& Castro-Alarcón, N. (2016). Gut microbiota and metabolic endotoxemia in young obese Mexican subjects. Obesity Facts, 9(1), 1-11.

Rajpal, D. K., Klein, J. L., Mayhew, D., Boucheron, J., Spivak, A. T., Kumar, V., ... Brown, J. R. (2015). Selective spectrum antibiotic modulation of the gut microbiome in obesity and diabetes rodent models. PLoS One, 10(12), e0145499.

Saad, M. J., Santos, A., \& Prada, P. O. (2016). Linking gut microbiota and inflammation to obesity and insulin resistance. Physiology, 31(4), 283-293.

Santos, R. M., \& Lima, D. R. (2016). Coffee consumption, obesity and type 2 diabetes: A mini-review. European Journal of Nutrition, 55(4), 1345-1358.

Schneeberger, M., Everard, A., Gómez-Valadés, A. G., Matamoros, S., Ramírez, S., Delzenne, N. M., ... Cani, P. D. (2015). Akkermansia muciniphila inversely correlates with the onset of inflammation, altered adipose tissue metabolism and metabolic disorders during obesity in mice. Scientific Reports, 5, 16643.

Song, H., Chu, Q., Yan, F., Yang, Y., Han, W., \& Zheng, X. (2016). Red pitaya betacyanins protects from diet-induced obesity, liver steatosis and insulin resistance in association with modulation of gut microbiota in mice. Journal of Gastroenterology and Hepatolology, 31(8), 1462-1469.

Tung, Y. C., Lin, Y. H., Chen, H. J., Chou, S. C., Cheng, A. C., Kalyanam, N., ... Pan, M. H. (2016). Piceatannol exerts anti-obesity effects in C57BL/6 mice through modulating adipogenic proteins and gut microbiota. Molecules, 21(11), 1419.

Wanchai, K., Pongchaidecha, A., Chatsudthipong, V., Chattipakorn, S. C., Chattipakorn, N., \& Lungkaphin, A. (2017). Role of gastrointestinal microbiota on kidney injury and the obese condition. American Journal of the Medical Sciences, 353(1), 59-69. 
Wang, J., Tang, H., Wang, X., Zhang, X., Zhang, C., Zhang, M., ... Shen, J. (2016). The structural alteration of gut microbiota in low-birth-weight mice undergoing accelerated postnatal growth. Scientific Reports, 6, 27780.

Wang, L., Zeng, B., Zhang, X., Liao, Z., Gu, L., Liu, Z., ... Fang, X. (2016). The effect of green tea polyphenols on gut microbial diversity and fat deposition in C57BL/6J HFA mice. Food \& Function, 7(12), 4956-4966.

Wegielska, I., \& Suliburska, J. (2016). The role of intestinal microbiota in the pathogenesis of metabolic diseases. Acta Scientiarum Polonorum Technologia Alimentaria, 15(2), 201-211.

Welly, R. J., Liu, T. W., Zidon, T. M., Rowles, J. L., Park, Y. M., Smith, T. N., ... VieiraPotter, V. J. (2016). Comparison of diet versus exercise on metabolic function and gut microbiota in obese rats. Medicine and Science in Sports and Exercise, 48(9), 16881698.

Xie, Z. M., Zhou, T., Liao, H. Y., Ye, Q., Liu, S., Qi, L., ... Pei, X-F. (2015). Effects of Ligustrum robustum on gut microbes and obesity in rats. World Journal of Gastroenterology, 21(46), 13042-13054.

Xu, P., Hong, F., Wang, J., Cong, Y., Dai, S., Wang, S., ... Zhai, Y. (2017). Microbiome remodeling via the montmorillonite adsorption-excretion axis prevents obesity-related metabolic disorders. EBioMedicine, 16, 251-261.

Yadav, H., Jain, S., \& Nagpal, R. (2016). Increased fecal viral content associated with obesity in mice. World Journal of Diabetes, 7(15), 316-320.

Yan, X., Feng, B., Li, P., Tang, Z., \& Wang, L. (2016). Microflora disturbance during progression of glucose intolerance and effect of sitagliptin: An animal study. Journal of Diabetes Research, 2093171.

Ziętak, M., Chabowska-Kita, A., \& Kozak, L. P. (2017). Brown fat thermogenesis: Stability of developmental programming and transient effects of temperature and gut microbiota in adults. Biochimie, 134, 93-98.

Zhang, X., Zhao, Y., Xu, J., Xue, Z., Zhang, M., Pang, X., ... Zhao, L. (2015). Modulation of gut microbiota by berberine and metformin during the treatment of high-fat diet-induced obesity in rats. Scientific Reports, 5, 14405.

Zschocke, A. K. (2016). Microbiome and winter flab. Deutsche Medizinische Wochenschrift, 141(25), 1823-1827. 
Duca, I., Rusu, F., Chira, A., and Dumitrascu, D. L.:

Microbiota and Body Weight

\title{
Microbioma intestinal y peso corporal - revisión
}

\begin{abstract}
Resumen
La relación entre la microbioma intestinal y la resistencia a la insulina tiene un impacto clínico importante dado que la gente afectada por disbiosis tiene predisposiciones para desarrollar la obesidad, la diabetes mellitus tipo 2, la enfermedad de hígado graso no alcohólico, cánceres, enfermedades cardiovasculares, neurodegenerativas y psiquiátricas. La disbiosis puede convertirse en una inflamación crónica, obesidad o síndrome metabólico. Hemos hecho una revisión sistemática de los estudios dedicados al papel de la microbioma intestinal para el aumento de peso y la obesidad. Una búsqueda sistemática de datos recientes publicados en las bases de datos electrónicas se ha llevado a cabo usando la frase "gut microbiome and body weight and obesity". Se ha excluido a los estudios que no contenían informaciones sobre la influencia de los cambios de la microbioma intestinal en la obesidad. La dieta occidental, uso de los antibióticos en la niñez, peso excesivo antes del embarazo, parto por cesárea y deficiencia de testosterona provocan la alteración de la microbioma y por consiguiente la apariencia de la obesidad. El predominio de firmicutes y géneros anaeróbicos, cambios en el microbioma y populación intestinal viral están implícitos en la etiología de la obesidad. Prebióticos, polifenoles, diferentes hierbas, medicamentos (antidiabéticos, calcio), ejercicio físico, consumo de fibras y cirugía bariátrica son las opciones terapéuticas más importantes. Tratamientos dietéticos personalizados, agentes antivirales y manipulación de la microbioma representarían nuevas metas en el tratamiento de la obesidad. Cada cambio en la composición cuantitativa o cualitativa de la microbioma influye en los componentes del síndrome metabólico, así que todas las estrategias para el tratamiento o prevención de la obesidad en niños o adultos deberían tener microbioma como su meta.
\end{abstract}

Palabras clave: diabetes, metabolismo, microbioma, obesidad

Received: October 23, 2017 
